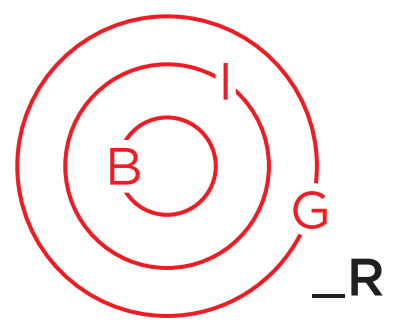

ART \& BORDERS

\title{
Beyond Borders, Beyond States: Artistic and Historical Aviation Perspectives
}

\author{
Ina Neddermeyer ${ }^{i}$ and Jürgen Bleibler ${ }^{\mathrm{ii}}$
}

Proceeding from the historical question of the regulation of airspace, this essay examines the current and future significance of borders and the central question of statehood, for the special section of this issue, Art \& Borders. The authors draw on their experience as curators of the 2021 exhibition Beyond States: The Boundaries of Statehood at the Zeppelin Museum in Friedrichshafen, Germany, to reveal the role of ballooning aviation and critical approaches of artists towards border regimes.

\section{Introduction}

In times of global markets and networks, progressing digitalisation, and the rise of supranational organisations, worldwide migration movements are no longer the exception but the rule. A development that poses great challenges to nation states. In this context, dissolving and simultaneously solidifying borders are central elements in the reflection on the multi-layered processes surrounding migration and statehood.

Besides their role as political and territorial instruments, borders are also determined by cultural, economic, social, and political reciprocity. As manifestations of a process, they impact national, social, and cultural structures of the present, past, and future with individual and collective perspectives that must be brought to light (Gerst et al. 2021).

Proceeding from the historical question of the regulation of airspace, this essay examines the current and future significance of borders and the central question of statehood.

\section{Border Violations and Confusions in the Sky: 18th Century Ballooning}

The question of drawing borders in the sky became relevant with the first forays into the third dimension with hot-air and gas balloons in 1783. Neither were steerable but became the basis for steerable motorised airships in the 20th century, which were soon rivalled by airplanes. Aviation was one of the most defining developments of the 20th century. As the epitome of modernity, it fundamentally changed mobility, science, and wars and provided a new perspective on Earth.

This view from above was glorified as the fulfilment of an ancient dream of mankind and associated with the desire to fly and freedom, but also represented the striving for technological superiority, the exercise of power, and conquest. Rooted in antiquity, the theoretical question of whether borders on the ground should extend to the sky became a concrete discussion about regulations in the wake of aviation (Otto 2017, 15-32).

i Ina Neddermeyer studied art history, political science, and philosophy in Berlin and Florence. From 2013 to 2016 she was the curator of the Municipal Art Collection at the Kunstpalais in Erlangen. Since 2016 she has been the curator and head of the art department of the Zeppelin Museum Friedrichshafen.

ii Jürgen Bleibler studied library science, art history, and German studies in Stuttgart and Saarbrücken. Since 1998, he has been the curator and head of the Zeppelin department of the Zeppelin Museum in Friedrichshafen. 
Borders in Globalization Review | Volume 3 | Issue 1 | Fall/Winter 2021

Neddermeyer \& Bleibler, "Beyond Borders, Beyond States: Artistic and Historical Aviation Perspectives"

\section{Evolution of Nation-States and Demarcations in Airspace}

In the 19th century, ballooning for military, scientific, or sporting purposes was the only practicable form of flying. Under favourable meteorological conditions, spherical balloons filled with hydrogen could cover distances of over 1,000 kilometres. But as neither the course nor the destination could be influenced, balloons went where the wind took them. Record and longdistance flights inevitably resulted in border crossings that often led to complications. On the ground, the appearance of balloons, especially over border fortifications and military installations, reinforced the unpleasant feeling of being at the mercy of surveillance from above. After landing, balloon crews were thus often confronted with accusations of espionage. The fact that many officers not only indulged in ballooning for competitive reasons further stoked these situations. Of course, the diplomatic climate between the state from which a balloon had set off and that in which it landed influenced the assessment of the situation. To avoid complications, participants in balloon races were legitimised with officially stamped multilingual membership cards.

In the 19th century, the formation of new nation-states required a basic regulation of the conception of national sovereignty. With the beginnings of aviation, airspace presented a new sovereignty issue that triggered a constitutional discourse.

Before the First World War, the controversy over the legal regulation of airspace was defined by two conflicting views. Those who advocated a national division were opposed by those in favour of an open sky. The main argument for the latter was that states could neither control nor defend their airspace, a theory the events of the First World War soon disproved.

The perception of balloons as threats to the sovereignty of states decreased with the advances in aviation technology. The focus had shifted to airships and airplanes. Besides idealistic hopes for a new form of transportation that would help to overcome borders and bring people together, the military potential of flying was the driving force. While aviation was taking shape as a new military option, the major European powers were engaged in a national prestige and arms race. In this political climate, flying reinforced the mutual distrust at state borders and stoked the fear of attacks from the third dimension.

Military decision makers in all states believed that airships and airplanes would aid the war on land through aerial reconnaissance. Due to their initially superior ranges and payloads, airships also gave rise to considerations on bombing. The discourse in international law about this new form of warfare is reflected in a ban imposed at the first Hague Peace
Conference in 1899. However, at the conference in 1907 it was lifted since none of the active nations wanted to relinquish this military advantage. The first step towards a potential aerial war without boundaries had thus been taken.

\section{Zeppelins as German Symbols of Power: Nationalism and Claims to Power Beyond Borders}

In the race for dominance in the third dimension, the German Empire mainly relied on the Zeppelin airships, which were built up by the media as a threat against France, and even more so, against Great Britain. On 1 July 1908, the Zeppelin airship LZ 4 flew from Lake Constance to Lucerne in Switzerland and back in twelve hours and made international headlines with this first transnational long-distance flight with a steerable aircraft. The unannounced intrusion into the airspace of a sovereign neighbour state was an unmistakable signal of the claim to power in the third dimension. It was not directed at Switzerland but caused alarm in the British Isles and unsettled the sense of absolute safety the nation's protected island position and the Royal Navy had provided for centuries. Reports of Zeppelins allegedly crossing over England to prepare for an imminent German invasion promptly started to amass. With the Aerial Navigation Act of 1911 as a direct response to the new threat, the British government was the first to pass a law on the closure of its own airspace (Otto 2017, 32).

In Switzerland, the state directly affected by Germany's border violation, the reactions were carried by a wave of Zeppelin euphoria any bit as enthusiastic as that in Germany. Even when LZ 4 crossed over military premises the officers responded with friendly waves. Nor did the Swiss government show any negative reactions, thus confirming their conflict-free diplomatic relationship with the German Empire. Only the Swiss Social Democrats referred to the flight as a violation of the country's sovereignty. For this they were instantly reprimanded by the SPD of Baden and Württemberg, who quickly persuaded their comrades in Switzerland to comply with the interpretation of the Zeppelin airship as an instrument of fraternisation between the two nations (Haude 2014, 9-15).

The 24-hour endurance fight of the LZ 4 on 4/5 August 1908 was a threatening gesture clearly directed against France. The mass circulation of images of the Zeppelin with the Strasbourg Munster was intended to reinforce the claim to Alsace-Lorraine, which had become part of the German Empire through an annexation during the Franco-Prussian War of 1870/71 [Figure 1]. Surprisingly, the destruction of LZ 4 in Echterdingen did not lead to technological disenchantment but to a "Volksspende (Donation of the People)", which manifested the collective identification with the popular "Airship Count". 
Borders in Globalization Review | Volume 3 | Issue 1 | Fall/Winter 2021

Neddermeyer \& Bleibler, "Beyond Borders, Beyond States: Artistic and Historical Aviation Perspectives"

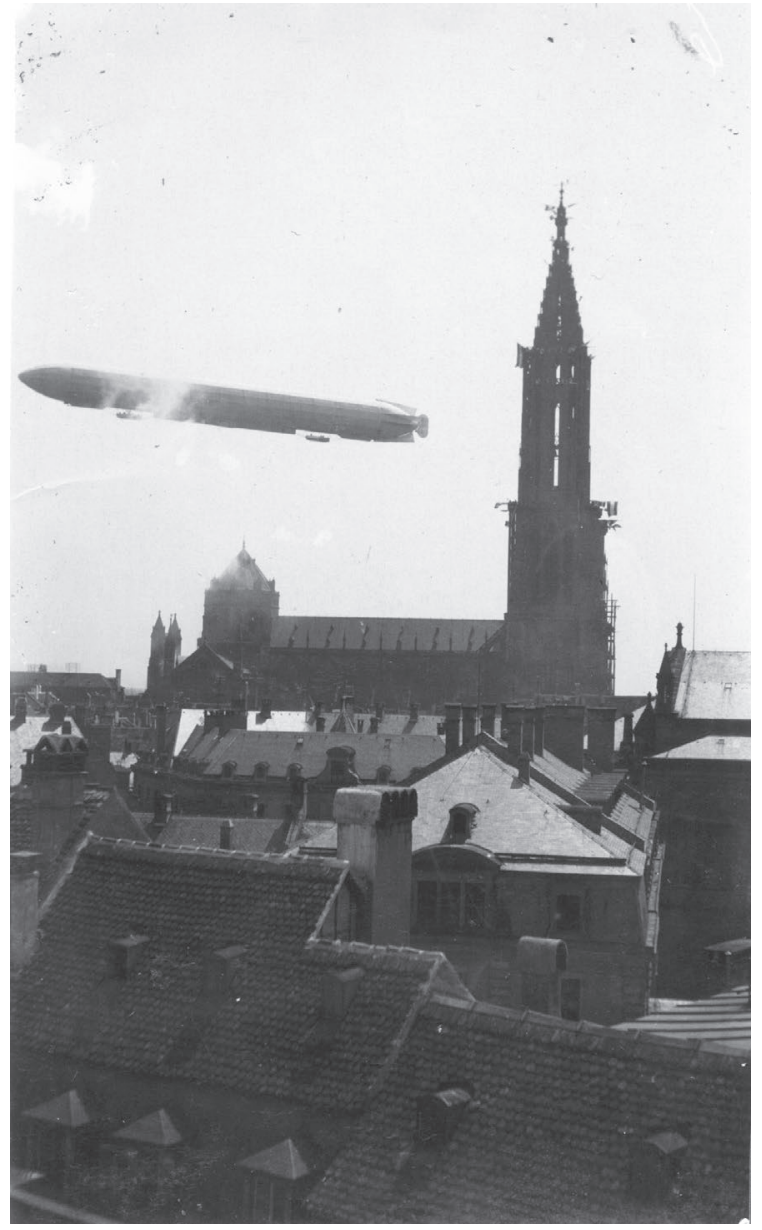

Figure 1. LZ 4 over Strasbourg 1904. (A) Archiv der Luftschiffbau Zeppelin $\mathrm{GmbH}$.
In addition to its external significance, the Zeppelin airship had gained an internal function as a symbol of national identity which helped to gloss over social conflicts and justify armament expenditures (Zeising 1998, 75-98).

\section{The Lunéville Incident of 1913}

The heated atmosphere at the French-German border became especially manifest in the Lunéville Incident of April 1913 [Figure 2]. On its way from Friedrichshafen to Baden-Oos, the army Zeppelin Z IV had gotten off course in the fog and was forced to make an emergency landing in Lunéville, France. While the French suspected espionage, the Germans were faced with the problem that the Zeppelin technology, a protected state secret, lay exposed on French territory where it could be photographed without hindrance and examined by experts in detail (de Syon 2001, 41-53).

The accusation of espionage was invalidated by the lack of cameras on board and the French accepted the loss of orientation as an explanation. However, this display of hopeless disorientation was extremely embarrassing for the German side and shook both the German military's and the public's faith in the Zeppelins' military adequacy. The reactions in the French populace were very hostile. One specific reason was that before landing, tools and spare parts had been thrown off $Z$ IV to shed ballast and had damaged some houses. In combination with the German propaganda's image of the airships as offensive weapons in a future war, this further fuelled the negative mood of the French.

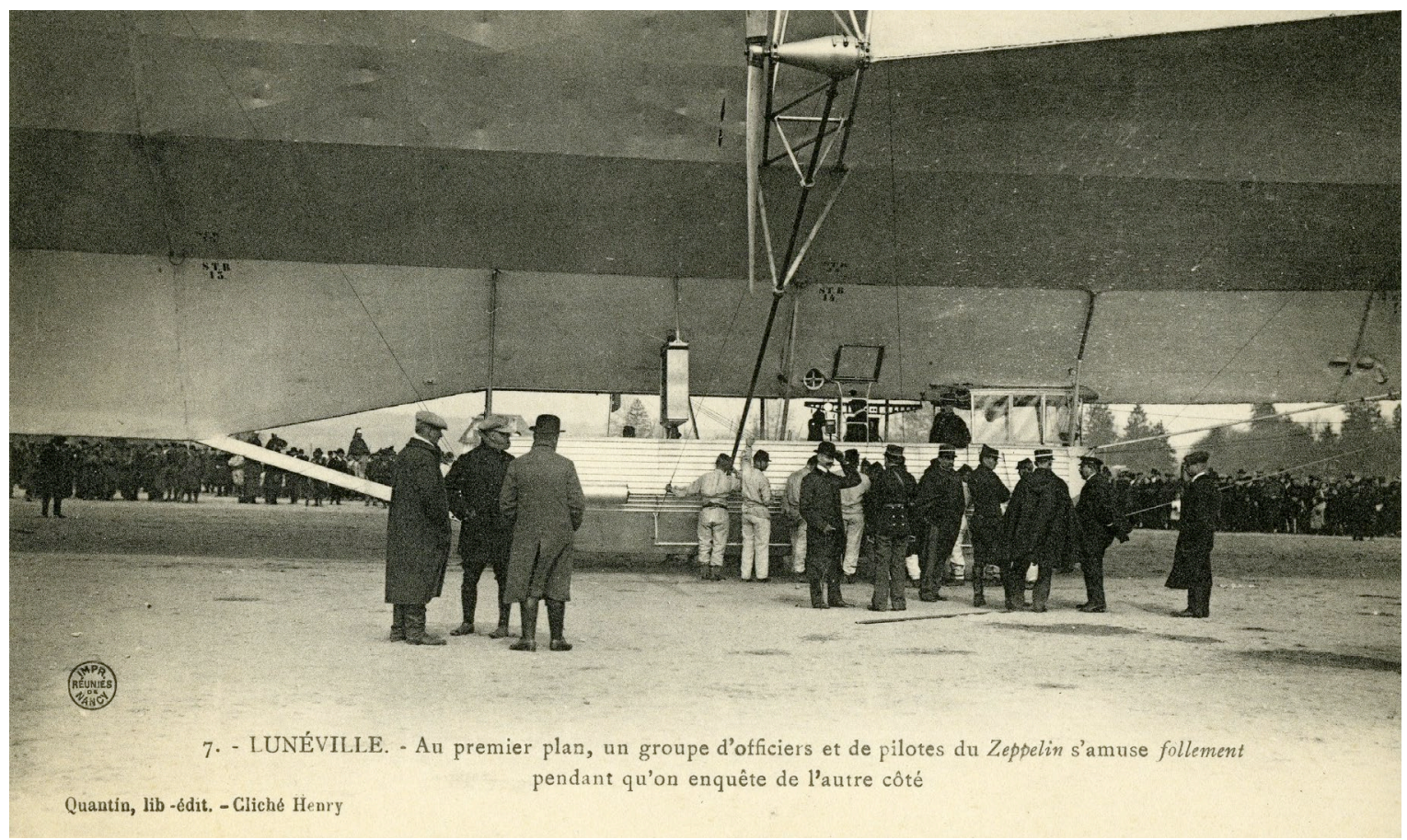

Figure 2. Lunéville incident 1913. ( $)$ Zeppelin Museum Friedrichshafen GmbH. 
Since 1900, the legal problems surrounding airspace such as national claims to sovereignty, open or closed airspace, liability in accident cases or field damage, violent offences on board aircraft, or dropping bombs in the event of war had become topics of discussion. The first initiatives for regulations came from France. As in Germany, confidence in the nation's technological superiority initially led to a preference for an open sky, in contrast to Great Britain. The need for a regulation of air traffic through international laws became apparent long before it was practicable. In 1910, a first exploratory conference was held in Paris. At the same time, the situation called for bilateral solutions between states, in which the distinction between civilian and military flight movements but also the political climate between the neighbours played an important role. In August 1913, a French-German aviation agreement was signed that regulated the obtainment of flyover permits and no-fly zones. However, it was hardly brought into action before the outbreak of the war. In 1919, by which time air traffic had become a realistic option due to the technological progress during the First World War, the decision was made to regulate airspace according to nation-states, which is still largely the case today.

\section{The First World War: Aerial Warfare without Boundaries and Civil Protection}

In the First World War, rigid airships of the Zeppelin and Schütte-Lanz construction type with their wide ranges and payloads revolutionised the possibilities of warfare by taking it far into the hinterlands of other states for direct attacks on industries, infrastructures, and civilian populations. Liège, Antwerp, Paris, and other cities were assailed by German airships, while German cities had already been targeted by French airplanes in 1914. Germany's strategic aerial war against previously unassailable Great Britain also played a special role in terms of war propaganda.

In May 1915, the first Zeppelin bombs were dropped on London. However, the pressure of increasing airship losses led to their replacement with airplanes from 1917 onwards. Airplanes were faster and cheaper to produce and required less professional and infrastructural effort. The First World War saw the escalation of this kind of aerial war across borders and great distances, which developed increasingly horrific dimensions. This advancement of aviation and weapons technology resulted in the death of countless civilians, first in the Spanish Civil War and subsequently during the Second World War.

This new form of attack from the third dimension raised the question of how to defend national airspace as well as civilian populations. Besides the establishment of defensive air forces, this included and continues to include the construction and maintenance of air-raid shelters, warning the population, and provisions for rescue measures, such as the recovery of people buried alive under rubble [Figure 3 ].

\section{Demarcations after 1945: The Cold War}

Since the 1950s, the development of intercontinental air traffic had gained dynamism and became a global means of mass transportation and an essential precondition for

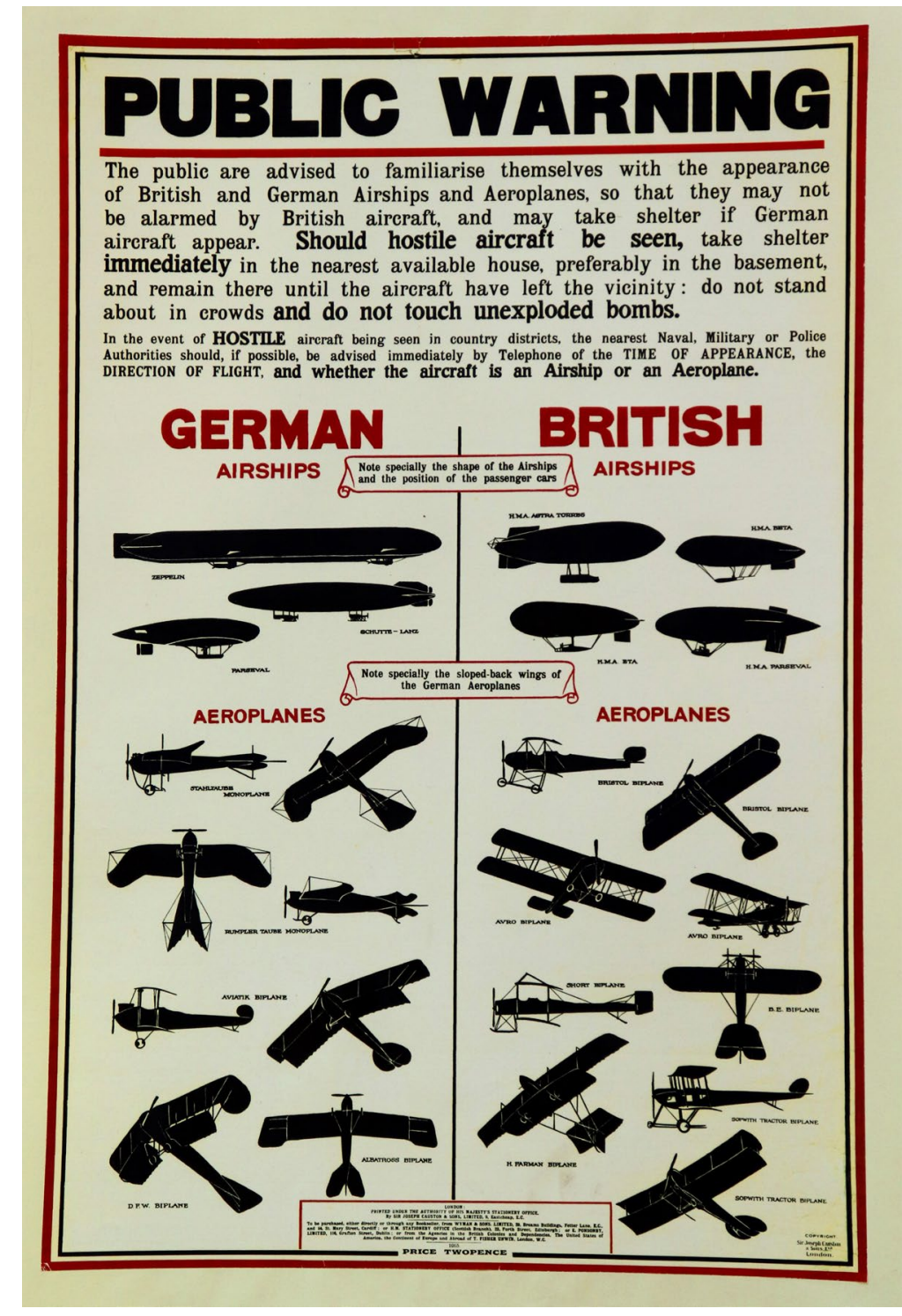

Figure 3. Public Warning (1915). ( $)$ Zeppelin Museum Friedrichshafen GmbH. 
globalisation in the 1970s. At the same time, the Cold War had drawn a new border through Europe which was also insurmountable in the sky. The two power blocs faced one another heavily armed with both conventional and nuclear weapons, which frequently triggered dangerous provocations and incidents. During the Cold War, attempts to transcend borders from the German Democratic Republic and other states by air were also made using the simplest means, such as home-made hot-air balloons. In 1987 Matthias Rust made headlines when he managed to enter the airspace of the USSR undetected from Finland and landws his hot-air balloon in the Red Square. More than ever, air traffic requires international and global conventions and is affected by every political, social, or cultural border shift, especially when a conflict is carried out with violent means.

\section{Fluid Demarcations}

Demarcations were not only contested in the sky. To this day, borders on water are not always clearly defined. In her work Border Sampling [N $47^{\circ} 37^{\prime} 26^{\prime \prime}$ E $9^{\circ} 22^{\prime}$ 32"'] Nevin Aladağ ponders questions of demarcation and state sovereignty by exploring Lake Constance as international boundary waters connecting Germany, Austria, and Switzerland. In some areas, the precise course of the border remains unclear [Figure 4]. From the German perspective, the Obersee, the Upper Lake, is a condominium, in other words, common territory beyond the shore. In accordance with common law, everyday life on Lake Constance is regulated by the International Lake Constance Conference which coordinates environmental and water protection across the borders. At the deepest point of Lake Constance, which is common sovereign territory, Aladağ took water samples and thereby exposed the paradoxical notion of water with its fluid mobility as a linear boundary mark [Figure 5]. The artist thus reflects on questions of border demarcation and state sovereignty.

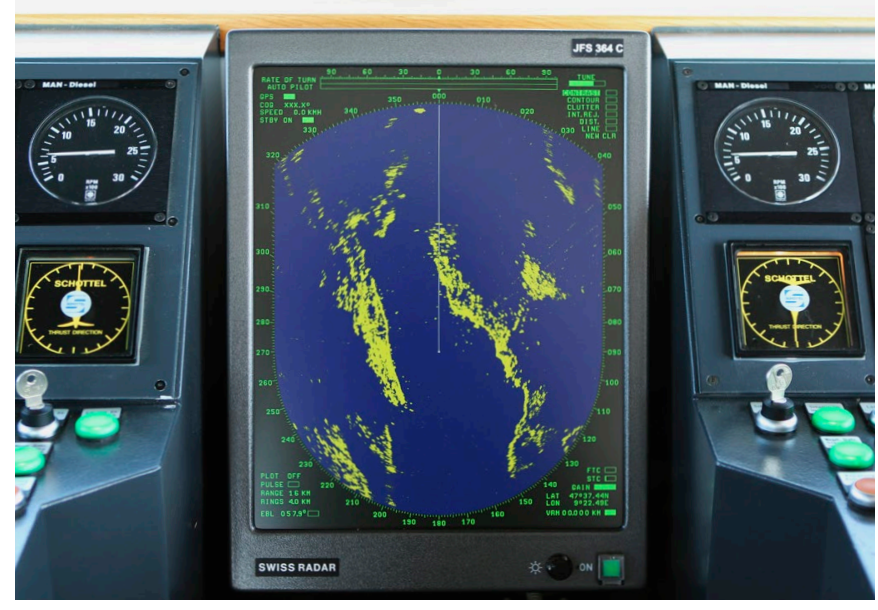

Figure 4. Nevin Aladag, Border Sampling, 2011. ( ) Nevin Aladağ, ZF Kunststiftung, VG Bild-Kunst 2021

\section{Militarised Border Regions}

Forensic Oceanography's work Mare Clausum-The Sea Watch vs Libyan Coast Guard Case (2018) deals with the militarised border region in the Mediterranean and shows how quickly fluid borders can became deadly danger zones. The collective analyses the spatial and political conditions that lead thousands of refugees to drown in the Mediterranean. This work is dedicated specifically to a grave incident that occurred on 6.11.2017 when the NGO Sea-Watch e.V. and the Libyan Coast Guard were called to save a boat carrying 130 migrants. Some of the refugees hoped to evade the Libyan catchers by swimming to the Sea-Watch rescue vessels. Sea-Watch managed to save 59 people who were taken to Italy. However, 47 people were taken back to Libya where they suffered severe human rights violations. At least 20 people died before and during the rescue operation [Figure 6].

Created with a selection of geodata, shipping data, models, video material from Sea-Watch e.V., eyewitness accounts, and leaked documents from the European Union Naval Force Mediterranean, the video reconstruction is a poignant illustration of the deadly effects of the EU's migration policies [Figure 7]. It is part of the "Mare Clausum" report by Forensic Oceanography, which served as the basis for a legal complaint against Italy at the European Court of Human Rights. For many years, the European Union has been externalising its border controls which recurringly leads to severe human rights violations. Despite its extensive budget, the European Border and Coast Guard Agency (Frontex) hardly conducts any rescue operations at sea; for context, in 2020 Frontex had a budget of $€ 460$ million (Monroy 2021). On the contrary, Frontex is frequently accused of being involved in illegal pushbacks and ignoring human rights standards. Moreover, the increasing criminalisation of civilian sea rescue missions has made the situation in the Mediterranean extremely dangerous.

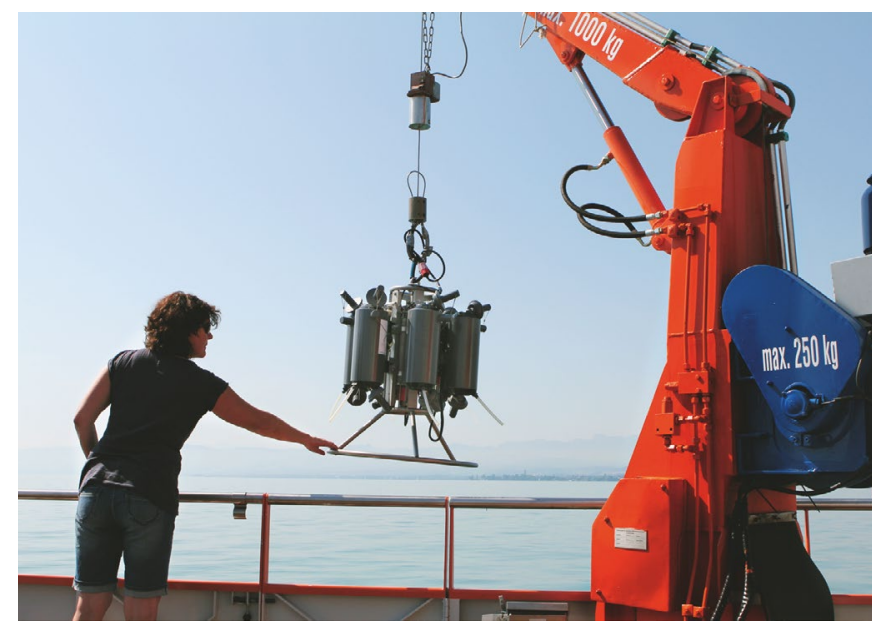

Figure 5. Nevin Aladag, Border Sampling, 2011. ( Nevin Aladağ, ZF Kunststiftung, VG Bild-Kunst 2021 


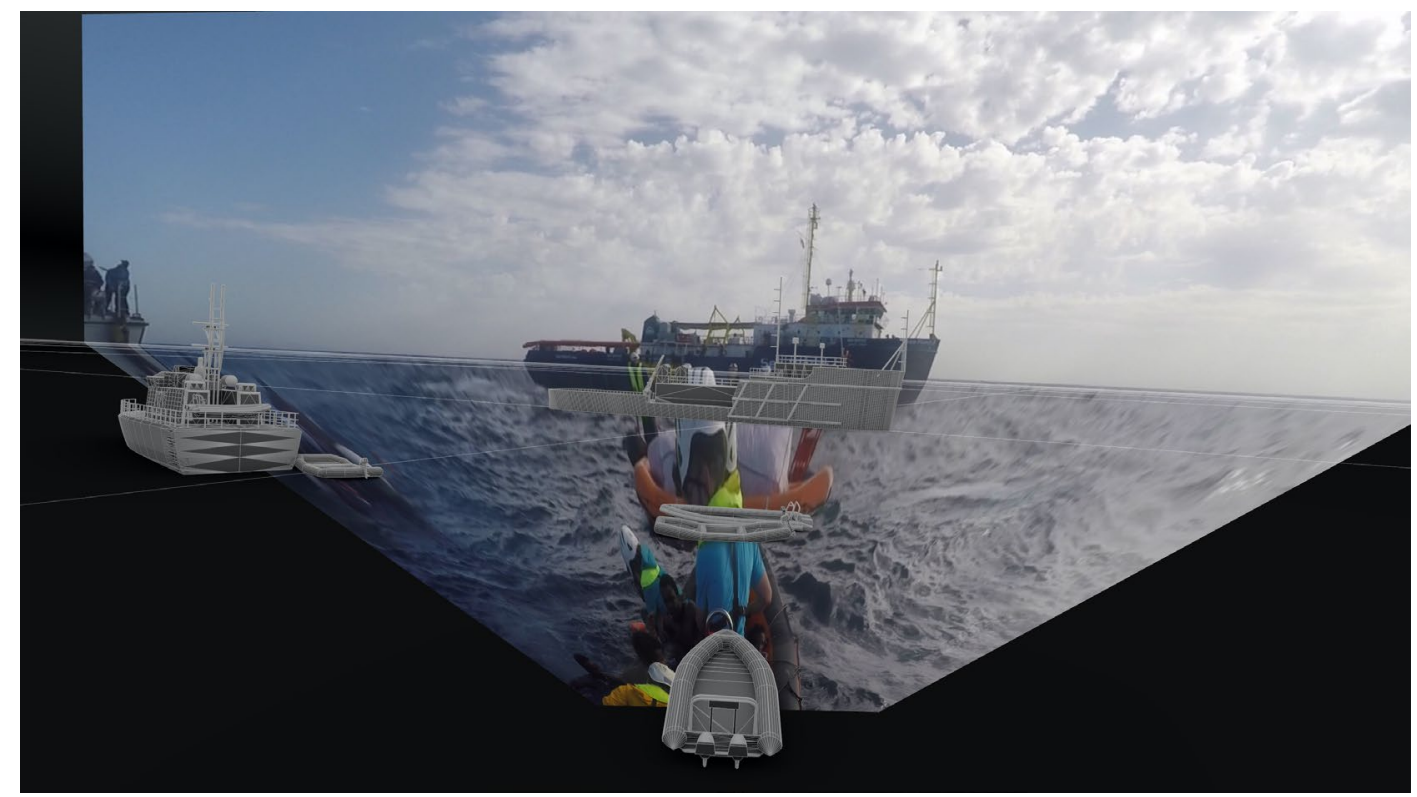

Figure 6. Forensic Oceanography and Forensic Architecture, Mare Clausum-The Sea Watch vs Libyan Coast Guard Case (2018, 28 min.). An image projected onto a 3D model in order reconstruct the complicated scene of search-and-rescue operations by the Libyan Coastguard and NGO vessels on 6 November 2017. (c) Forensic Oceanography and Forensic Architecture, 2018.

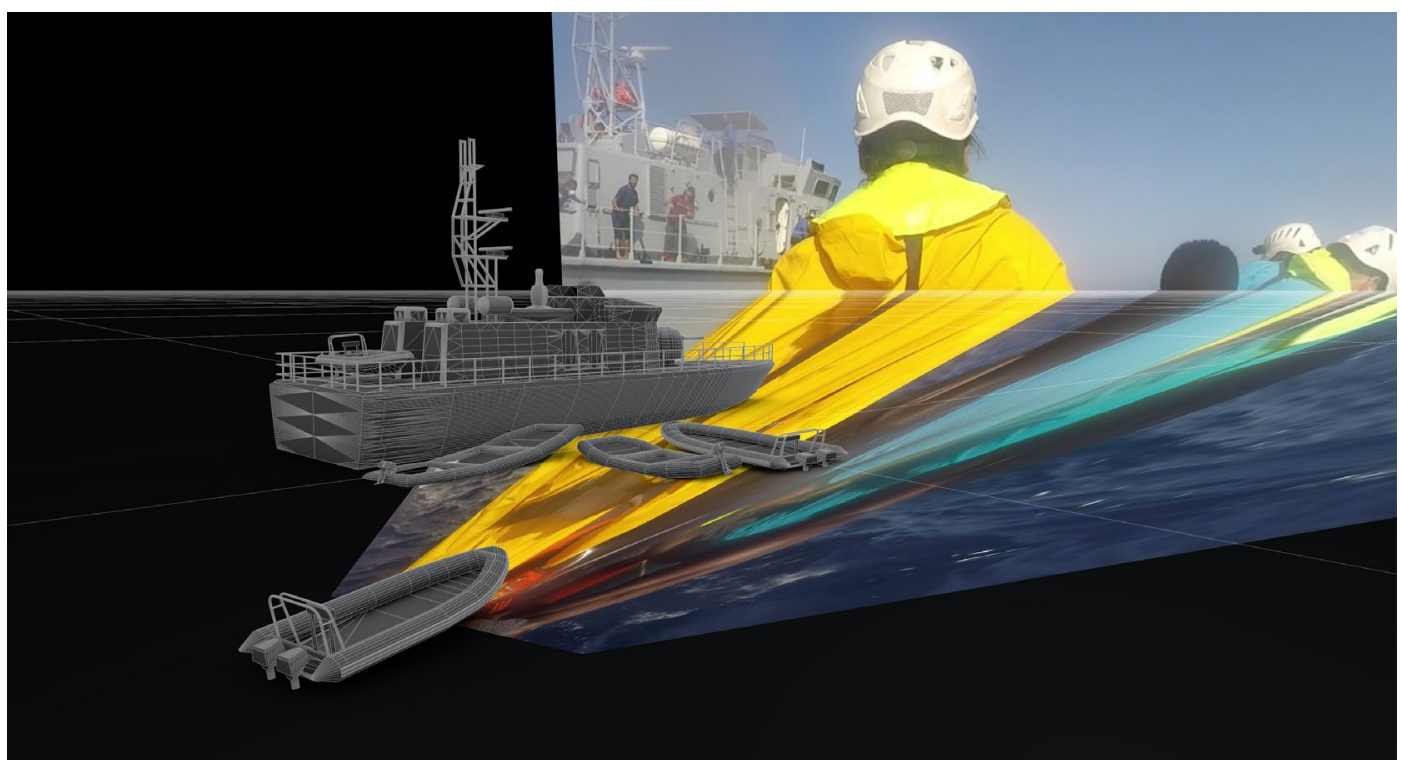

Figure 7. Forensic Oceanography and Forensic Architecture, Mare Clausum-The Sea Watch vs Libyan Coast Guard Case (2018, $28 \mathrm{~min}$.). A reconstruction of the altercation of search and rescue operations in the central Mediterranean on 6 November 2017. ( F Forensic Oceanography and Forensic Architecture, 2018.

Forensic Oceanography's video installation reveals the failure of government institutions in the countries thousands are forced to flee from due to their extreme economic and political situations, the Libyan Coast Guard and its increasing use of violence against migrants, and the inability of the European border states to find a humanitarian solution. Charles Heller (Forensic Oceanography) strongly advocates legal and safe refugee routes and refers to the bigger picture in which migration is a manifestation of socio-economic problems:
From my perspective, the last 30 years of policies of border closure demonstrate how utopian it is to try to seal borders and prevent mobility. If those politics could work, I think we would know it after 30 years. They failed miserably. They only generate further human suffering, but also political crises. I think it is much more effective to start from the fact of human movement. That is the reality. Give a legal frame for that human movement to unfold and really try to tackle the broader political economic conflicts and inequalities that today make migration so contentious (Heller 2021). 
Borders in Globalization Review | Volume 3 | Issue 1 | Fall/Winter 2021

Neddermeyer \& Bleibler, "Beyond Borders, Beyond States: Artistic and Historical Aviation Perspectives"

\section{How to Overcome Borders: Flexible Citizenship}

The question of how to overcome borders and establish new forms of citizenship concerns many artists. All over the world, citizenship is still tied to nation-states. But what shape could a flexible kind of citizenship take?

In their video, Jacob Hurwitz-Goodman and Daniel Keller critically explore the Seasteading Institute which wants to establish autonomous communities on swimming platforms on international waters [Figure 8]. They propagate a new kind of settlement (ocean instead of land grabbing) beyond national borders. What initially seems like a both utopian and progressive project geared towards enabling new forms of coexistence, turns out to be a neoliberal idea mainly motivated by tax evasion. The governments of the new microstates resemble businesses on a free market where citizens can choose their favourite society.

Christopher Kulendran Thomas and Annika Kuhlmann went one step further with their examination of postcapitalist societal models beyond national borders. They developed a housing proposal that combines the idea of a flexible network-like state as an alternative to a territorially limited nation with design concepts. The work was inspired by the lost stories of the home country of Kulendran Thomas's family. Once a part of Sri Lanka, Tamil Eelam was in effect an autonomous state self-governed by a neo-Marxist revolution for decades before it was wiped out with the brutal end of the Sri Lankan civil war in 2009.
Kulendran Thomas and Kuhlmann studied the work of the revolutionary Tamil architect Manmahal (மண்மகள்). During the time of Tamil Eelam, her ideas for a flexible, decentralised housing network envisioned a future beyond the caste system and other social forms imposed under British colonial rule. Manmahal's designs for a flexible furniture system were reinterpreted in collaboration with the Berlin designers NEW TENDENCY [Figure 9]. The concept is based on a single joint that can be combined with locally available materials to construct a variety of furniture. The underlying idea of transnational mobility functions beyond national borders. Flexible citizenship and design are interpreted as a mutually influential unity.

\section{Beyond Border, Beyond States}

The past years have seen a worldwide transformation process in which classic border security policies are being replaced by smart border management. This development is accompanied by an increased technologization of borders enhanced by robotics and artificial intelligence. However, this is where the basic conflict soon becomes apparent: the paradoxical endeavour of securing borders while trying to enable as much mobility as possible at the same time (Pötzsch 2021, 283-296).

Not only Christopher Kulendran Thomas, but also the artist Jonas Staal, explores decentralised forms of coexistence. In 2012, Staal initiated the New World

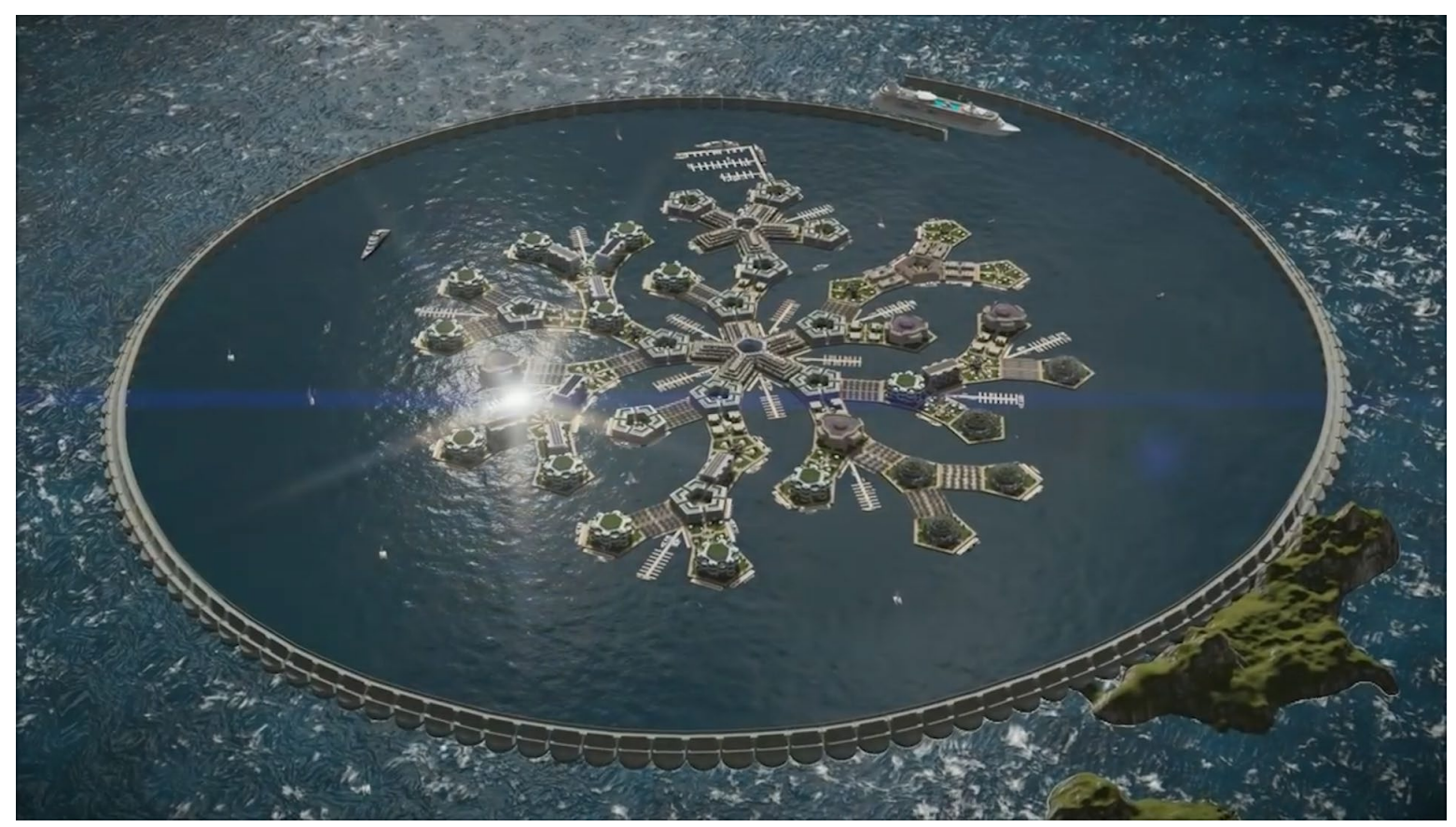

Figure 8. Jacob Hurwitz-Goodman \& Daniel Keller, The Seasteaders (2018, 28 min.). The. video still shows a preliminary design for the seasteading community. (c) the artists. 


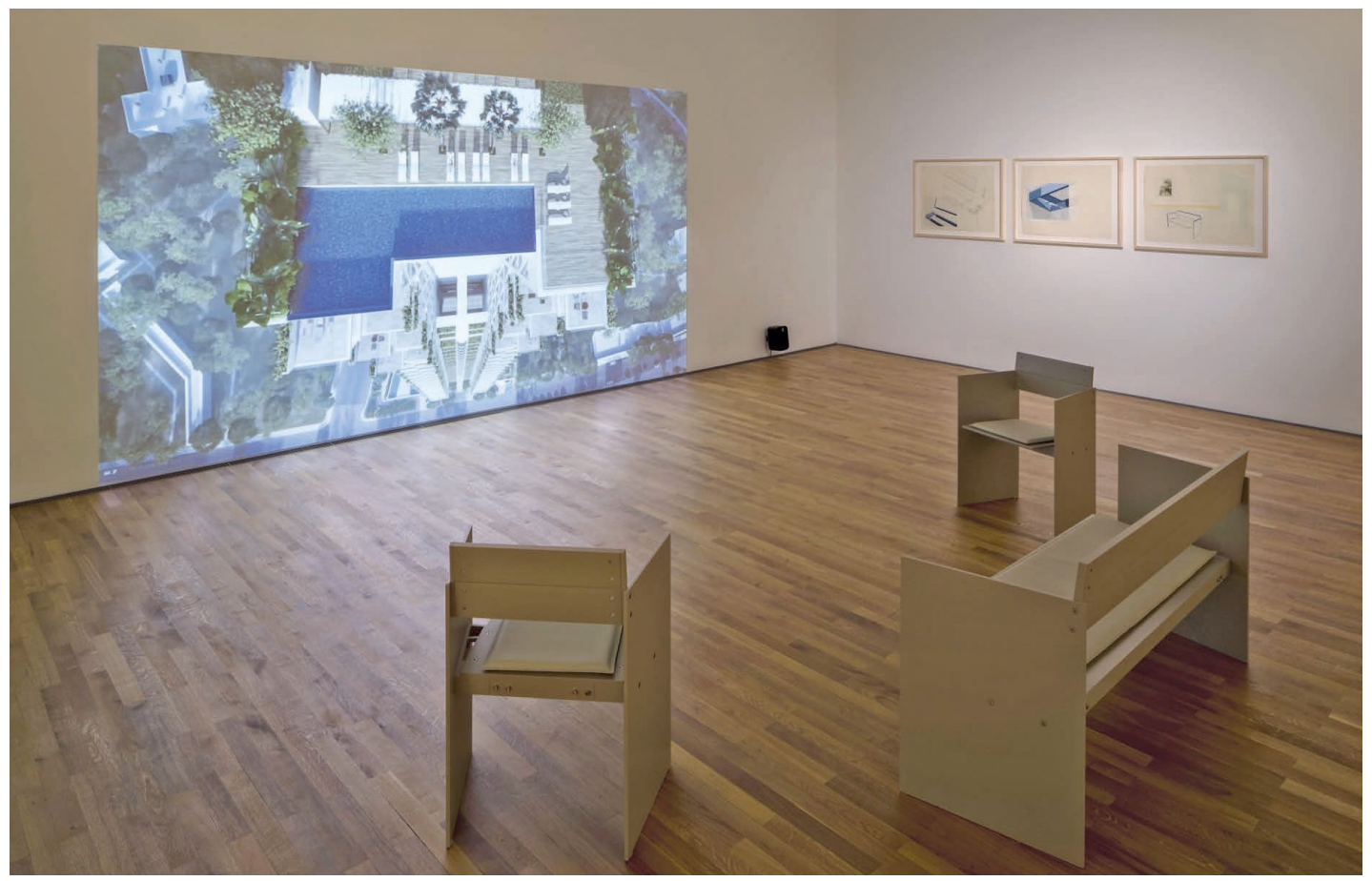

Figure 9. Christopher Kulendran Thomas, 60 Million Americans Can't Be Wrong (2017, 24 min.). In collaboration with Annika Kuhlmann. Includes prototypes for modular seating after Manmahal (மண்மகள்), designed by NEW TENDENCY in aluminum, leather; and studies for modular seating after Manmahal (மண்மகள்) in collaboration with NEW TENDENCY in watercolour, gouache, and coloured pencil on paper. (c) the artists.

Summit, a kind of parliament for stateless organisations. Since then, the congress has taken place several times at different locations. Some of the participating organisations operate outside political systems and are therefore regarded as terrorist organisations. Besides the temporary parliaments, there are also long-term projects, such as the construction of an autonomous parliament in Rojava (Northern Syria), which is to become a permanent institution (Figure 10). In this context, Staal investigates the concept of stateless democracy and its emancipatory potential. The Kurdish revolutionary movement, for instance, is decidedly critical of the role of the state: "The state is not so much something that represents independence or sovereignty, but something that reproduces an imperialist dependency" (Staal 2021). Thus, Staal wonders:

Can the nation state as we know it, as an overlapping understanding of territory and nation and a structure of governance, can this truly address the planetary crisis that we are now facing? The intersection of political, economic, humanitarian, ecological crisis? The work, in this case specifically of the Kurdish revolutionary movement, opens pathways to start thinking of forms of collective self-governance that certainly have social contracts, that do not deny the needs of equivalent forms of constitutions (ibid).
These demands call very specifically for self-governing structures that act locally and regionally and transcend the borders of nation states:

A great challenge in rethinking or reimagining the need for transnational forms of politics, planetary forms of politics, forms of politics that stretch our social contracts beyond the limitations of the nation state, is to think of how not to fall into the trap of the globalist idea that reproduces homogenous culture, that aims to reproduce the same form of capitalist democracy across the globe (ibid).

The examination of borders and demarcations is a fundamental undertaking as it questions the very essence of the state and propagates new forms of coexistence.

\section{About the exhibit}

\section{Beyond States. The Boundaries of Statehood}

$05.02 .2021-07.11 .2021$

Curators: Dr. Claudia Emmert, director, Ina Neddermeyer, head, and Caroline Wind, research assistant of the art department at the Zeppelin Museum, Jürgen Bleibler, head, and Felix Banzhaf, research assistant at the scientific department at the Zeppelin Museum. 


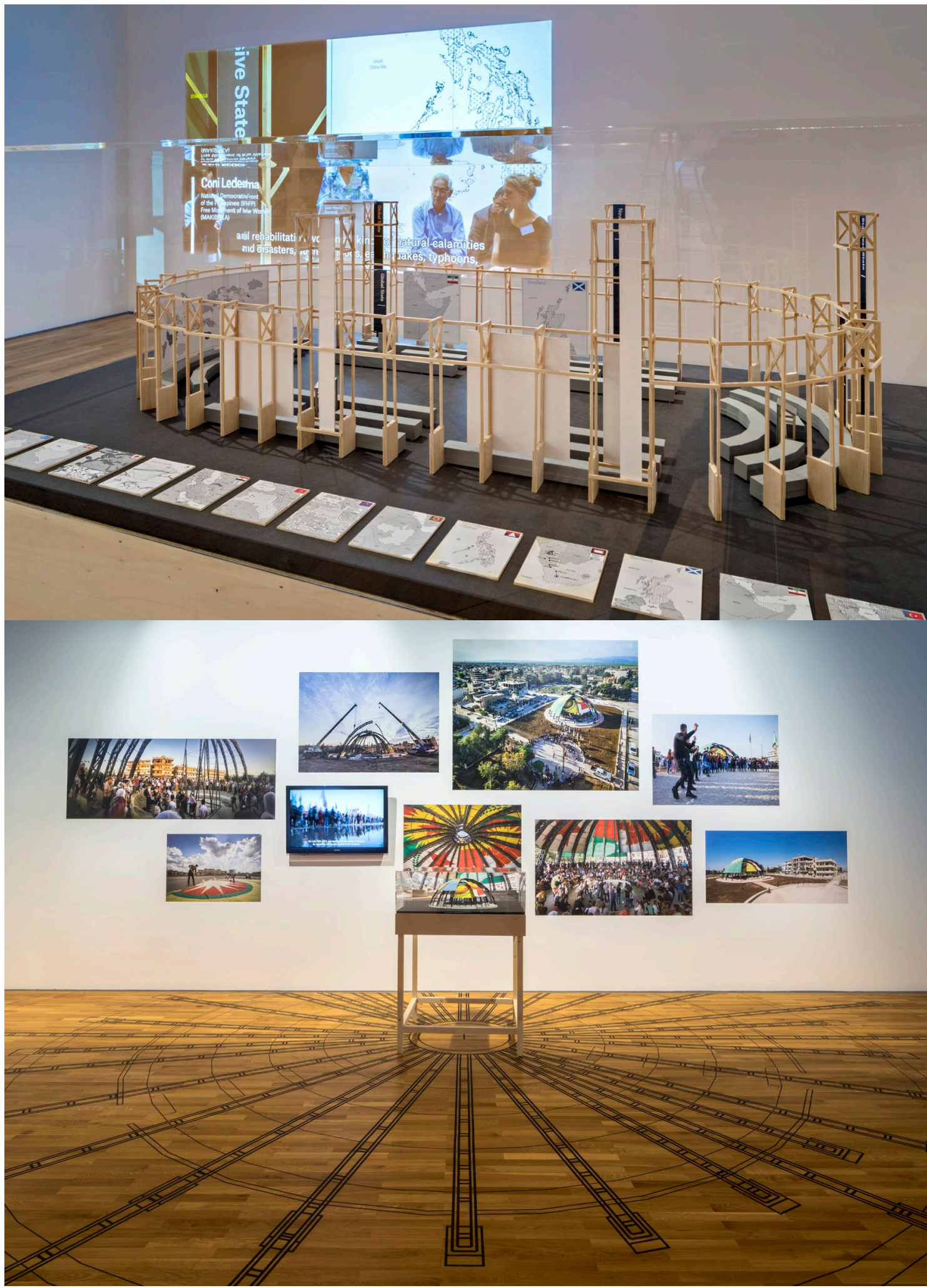

Figure 10. Jonas Staal, New World Summit-Rojava (2015-2018, video, 3 min). Architectural Model, Floorprint, Wall Collage, Zeppelin Museum, Foto Tretter. The New World Summit-Rojava consists of two parts: a commission by the autonomous government of Rojava (northern Syria) to design and construct a new public parliament and an international summit in the region. 
Borders in Globalization Review | Volume 3 | Issue 1 | Fall/Winter 2021 Neddermeyer \& Bleibler, "Beyond Borders, Beyond States: Artistic and Historical Aviation Perspectives"

Invited artists: Nevin Aladağ, James Bridle, Simon Denny, Vera Drebusch \& Florian Egermann, Forensic Oceanography/ Forensic Architecture, Jacob HurwitzGoodman \& Daniel Keller, Peng! Kollektiv, Christophetr Kulendran Thomas, Henrike Naumann, Jonas Staal.

Zeppelin Museum Friedrichshafen

Director: Dr. Claudia Emmert

Seestr. 22

88045 Friedrichshafen

www.zeppelin-museum.de

PRESS ZEPPELIN MUSEUM

Simone Lipski +49 (0) $7541-380121$

lipski@zeppelin-museum.de

\section{Works Cited}

de Syon, Guillamue. 2001. "Zwischen Hightech und Kavallerie. Der Lunéville-Zwischenfall von April 1913" in Wolfgang Meighörner (eds.), Zeppelin Museum Friedrichshafen. Wissenschaftliches Jahrbuch, Friedrichshafen.

Dominik Gerst, Maria Klessmann, and Hannes Krämer (eds.). 2021. Grenzforschung: Handbuch für Wissenschaft und Studium. Baden-Baden.

Haude, Rüdiger. 2014. "Überwältigend. Zur politischen Bedeutung der Schweizfahrt des LZ 4 am 1. Juli 1908" in Ursula Zeller et al. (eds.), Zeppelin Museum Friedrichshafen.
Wissenschaftliches Jahrbuch Band 11, Friedrichshafen.

Heller, Charles. 2021. "Online Assembly: Beyond BordersScreening 'Mare Clausum' and Charles Heller Artist Talk" Youtube, Zeppelin Museum Friedrichshafen, 1:29:24 (accessed 17 March 2021) https://www.youtube.com/ watch?v=7XsDOClcJTI

Monroy, Matthias. 2021. "Frontex Files: Der Militärischgrenzpolizeiliche Komplex" Netzpolitik (accessed 17 March 2021). https://netzpolitik.org/2021/frontex-filesder-militaerisch-grenzpolizeiliche-komplex/

Otto, Dietrich W. 2017. "Die Entwicklung der Regulierung der Luftfahrt in Hinsicht auf die Globalisierung 1783-1947" Zurich. Basel, Geneva.

Pötzsch, Holger. 2021. "Grenzen und Technologie" in Dominik Gerst, Maria Klessmann, Hannes Krämer (eds.), Grenzforschung: Handbuch für Wissenschaft und Studium. Baden-Baden.

Stall, Jonas. 2021. “Online Assembly: Beyond Borders-Artist Lecture \& Talk: Jonas Staal” Youtube. Zeppelin Museum Friedrichshafen, 1:17:23 (accessed 17 March 2021). https:// www.youtube.com/watch?v=PQ2p-OQUiRA\&t=1s

Zeising, Jeannine. 1998. "Reich und Volk für Zeppelin! Die journalistische Vermarktung einer technologischen Entwicklung" in Wolfgang Meighörner (eds.), Zeppelin Museum Friedrichshafen. Wissenschaftliches Jahrbuch, Friedrichshafen. 